\title{
Analysis of Purchasing Decisions Based on Sales Promotion and Service Quality
}

\author{
Ali Maddinsyah \\ Universitas Pamulang \\ Email: alimaddinsyah@gmail.com
}

(Received: Februari 15-2020; revised: June 12-2020; published: June 30-2020)

\begin{abstract}
This research aims to analyze purchasing decisions based on sales promotions and service quality at Giant Ekspres Pondok Cabe, South Tangerang. The method of data analysis is using quantitative associative analysis techniques where the population is 32,866 consumers, sampling, the author uses the Slovin formula with an error rate of $10 \%$ where after calculating the number of samples obtained as much as 99.69 rounded up to 100 Respondents. There is a significant simultaneous effect between sales promotion and service quality on purchasing decisions at Giant Express Pondok Cabe. This is indicated by the value of Fcount> Ftable $(1990,740>3.09)$ and significance of 0,000 . The effect is based on the value of the R determination coefficient which is equal to 0.976 . This means that variations in Sales Promotion and Service Quality variables explain the variation in the purchase decision variable is $97.6 \%$ and the difference of $2.4 \%$ is explained by factors that are not examined.
\end{abstract}

Keywords: purchasing decision, promotion, service quality

\section{INTRODUCTION}

Retail business is the whole activity of selling goods or services directly to consumers that are used to meet their personal needs and not to be used for business needs or further processing. (Maruf, 2006; Soliha, 2008; Utomo, 2010) Every company that sells directly to end consumers, producers, wholesalers, and retailers can be said to act in the retail business. The rapid development of modern retail is based on the company's desire to meet the needs of its customers (Sarwoko, 2008; Utomo, 2011). Someone buys goods or services because of wants and needs. In addition there are functional needs related to routines such as meeting family needs, finding low prices, and so on. At this time customer behavior has been a shift in behavior (behavior change). Behavior of people who shop with planned to be unplanned. People who are unplanned think short and look for the instant and look for products that can provide short-term benefits to solve problems that are in plain sight. According to (Kotler, 2011), the specific purchasing process consists of the following sequence of events: problem recognition, information search, alternative evaluation, purchase decision and post-purchase. The job of the marketer is to understand the behavior of the buyer at each stage and the influence of what works at that stage. According to the American Marketing Association cited by (Kotler \& Keller, 2009), marketing is an organizational function and a series of processes to create, communicate, and provide value to customers in ways that benefit the organization and stakeholders.

Marketing management seeks to regulate the level, time and order of existing requests, in order to help the organization achieve its goals (Hollensen, 2010; Peter, Olson, \& Grunert, 
86| Jurnal Ilmiah Ilmu Administrasi Publik: Jurnal Pemikiran dan Penelitian Administrasi Publik Volume 10 Number 1, January- june 2020. Page 85-90

1999; Scriven, Clemente, Dawes, Trinh, \& Sharp, 2017). Marketing management occurs when at least one party in a potential exchange thinks about ways to achieve the response the other party wants (Kotler \& Keller, 2015), marketing management as a science of choosing target markets to grow and understand customers.

Understanding promotion (Rangkuti, 2013), promotion is one of the elements in the company's marketing mix that is used to inform, persuade, and remind about company products ". Understanding promotion according to (Kotler and Armstrong, 2008), promotion is an activity that communicates the benefits of the product and persuades customers to buy the product. In carrying out promotional activities there are various means of promotional tools designed to increase sales volume. Sales promotion is a short-term incentive to encourage desire and to try or buy a product (Deng, Staelin, Wang, \& Boulding, 2018; Scriven et al., 2017; Yang $\&$ Mattila, 2020). Along with economic growth and technological advancements, the business world today. Where companies compete with each other to dominate the market share.

According to Lewis and Booms in (Tjiptono, 2004) states that a measure of how good the level of service provided is able to match customer expectations. The quality of a dynamic condition related to products, services, people, processes, and the environment that meets or exceeds expectations (Granero, 2019; Han \& Chouinard, 2014; van Ooijen, Fransen, Verlegh, \& Smit, 2017). Understanding of promotional tools that consumers do not understand, service quality is not good, so consumers are less interested in shopping. In addition, the lack of responsiveness in addressing the complaints of consumers conveyed by consumers, thus hampering the purchase decision to use products from the Pondok Cabe Pondok Ekspres Tangerang Selatan.

\section{METHOD}

The study was conducted at the Giant Ekspres Pondok Cabe outlet, Jl RE. Martadinata No.1, Pamulang, South Tangerang. Tel 021- 7478020, fax 021-7478020. The population in this study is consumers shopping at Giant Express Pondok Cabe that has been set by researchers, namely consumers in one year in 2017. The type of research is associative quantitative, the number of samples taken in this study is determined by the Slovin formula (Siregar, 2010: 149) with the formula:

$$
n=\frac{N}{1+N e^{2}}
$$

Table 1

Data on Number of Consumers Who Shop at Pondok Ekspres Giant Express outlets Month: September to December 2017

\begin{tabular}{ll}
\hline Month & Number of Consumers \\
\hline September & 33000 Consumers \\
October & 34100 Consumers \\
November & 31500 Consumers \\
\hline
\end{tabular}


Sumber : Gerai Giant Ekspres Pondok Cabe

The population of 32,866 consumers. Then from the formula above we get $\mathrm{n}$ value of 99.69. So that the number of respondents who will be made into a sample is rounded to 100 respondents.

\section{RESULT AND DISCUSSION}

From the results of testing the statistical hypothesis and analysis, an analysis of service quality based on sales promotions and service quality at the Giant Ekspes Pondok Cabe is as follows:

\section{Effect of Sales Promotion on Consumer Purchasing Decisions on Giant Express Pondok Cabe}

The correlation between sales promotions and consumer purchasing decisions is 0.954 . It can be said that there is a positive relationship of 0.954 between the variable sales promotion with consumer purchasing decisions on the Giant Express Pondok Pondok. The regression model obtained is $\mathrm{Y}=-5.035+0.670 \mathrm{X} 1 \mathrm{R}$ of 0.910 . The data indicates that sales promotion contributed $91.0 \%$ to consumer purchasing decisions at Giant Ekspres Pondok Cabe. Tcount value of 31,530 with a significance of 0,000 . Value of $t$ table $=t(0.05 ; 97)=1.660$. Because $t_{\text {count }}>t$ table $(31,530>1,660)$ and the significance of $t<0.05(0,000<0.05)$ means that $\mathrm{H} 10$ is rejected and H1>0 is accepted. This shows that the sales promotion variable has a positive and significant influence on purchasing decisions at Giant Ekspres Pondok Cabe.

\section{Effect of Service Quality on Purchasing Decisions on Giant Express Pondok Cabe}

The correlation between service quality and consumer purchasing decisions is 0.986 . It can be said that there is a positive relationship of 0.986 between service quality variables with consumer purchasing decisions at the Pondok Cabe Giant Express. The regression model obtained is $\mathrm{Y}=-6,122+0,478 \mathrm{X} 2 \mathrm{R}$ of 0,973 . These data indicate that service quality contributed $97.3 \%$ to consumer purchasing decisions at the Giant Ekspres Pondok Cabe. Tcount value of 59,003 with a significance of 0,000 . Value of $t$ table $=t(0.05 ; 97)=1.660$. Because $\mathrm{t}_{\text {count }}>\mathrm{t}$ table $(59.003>1,660)$ and significance $\mathrm{t}<0.05(0.000<0.05)$ means that $\mathrm{H} 20$ is rejected and H2>0 is accepted. This shows that the variable quality of service has a positive and significant effect on purchasing decisions on the Giant Express Pondok Pondok.

\section{The Effect of Sales Promotion and Service Quality together on Purchasing Decisions on Pondok Cabe Giant Express}

The regression model obtained is $\mathrm{Y}=-6,403+0,132 \mathrm{X} 1+0,391 \mathrm{X} 2$. Service quality variable (X2) has a positive effect on consumer purchasing decisions (Y) with a coefficient value of 0.391 which means that if the service quality variable (X2) increases by one unit assuming the variable sales promotion (X1) remains, then the consumer purchasing decision (Y) will increased by $0.391 . \mathrm{R}$ is 0.976 . The data indicates that sales promotion and service quality contributed $97.6 \%$ to consumer purchasing decisions at the Giant Express Pondok Pondoke, while the remaining $2.4 \%$ was influenced by factors not examined. Fcount value of 1990.740 with a significance of 0,000 . Value $F$ table $=F(0.05 ; 97)=3.09$. Because $F_{\text {count }}>F_{\text {table }}$ 
88 | Jurnal Ilmiah Ilmu Administrasi Publik: Jurnal Pemikiran dan Penelitian Administrasi Publik Volume 10 Number 1, January- june 2020. Page 85-90

$(1990.740>3.09)$ and significance $\mathrm{t}<0.05(0.000<0.05)$. Means $\mathrm{H} 30$ is rejected and $\mathrm{H} 3>0$ is accepted. This shows that the variable of sales promotion and service quality has a positive and significant effect on purchasing decisions at Giant Ekspres Pondok Cabe.

\section{CONCLUSION}

Based on the results of the study, it was found that sales promotion was proven to have a positive and significant effect on consumer purchasing decisions on the Giant Ekspres Pondok Cabe. Service quality is proven to have a positive and significant influence on consumer purchasing decisions at Giant Ekspres Pondok Cabe. There is a significant simultaneous effect between sales promotion and service quality on purchasing decisions at Giant Express Pondok Cabe. This is indicated by the value of $F_{\text {count }}>F_{\text {table }}(1990,740>3.09)$ and significance of 0,000 . The effect is based on the value of the $\mathrm{R}$ determination coefficient which is equal to 0.976 . This means that variations in Sales Promotion and Service Quality variables explain the variation in the purchase decision variable is $97.6 \%$ and the difference of $2.4 \%$ is explained by factors that are not examined.

\section{REFERENCES}

Deng, Y., Staelin, R., Wang, W., \& Boulding, W. (2018). Consumer sophistication, word-ofmouth and "False" promotions. Journal of Economic Behavior \& Organization, 152, 98123. https://doi.org/https://doi.org/10.1016/j.jebo.2018.05.011

Granero, L. M. (2019). Strategic product variety and quality choice. Economics Letters, 182, 10-14. https://doi.org/https://doi.org/10.1016/j.econlet.2019.05.033

Han, B., \& Chouinard, H. H. (2014). Product quality, advertising intensity and market size. Economics Letters, 124(2), 215-218. https://doi.org/https://doi.org/10.1016/j.econlet.2014.05.020

Hollensen, S. (2010). Marketing management: A relationship approach. Pearson Education.

Kotler dan Amstrong. (2008). Prinsip-Prinsip Pemasaran Jilid I. In Erlangga.

Kotler, P. (2011). Manajemen Pemasaran (terjemahan). In Edisi Millenium, Jilid 1.

Kotler, P., \& Keller, K. L. (2009). Manajemen pemasaran Jilid 1. In Jakarta.

Kotler, P., \& Keller, K. L. (2015). Marketing Mangement. In Pearson Edition Limited.

Maruf, H. (2006). Pemasaran Ritel. In Jakarta: Gramedia Pustaka Utama. https://doi.org/10.1007/s10872-006-0051-9

Peter, J. P., Olson, J. C., \& Grunert, K. G. (1999). Consumer behaviour and marketing strategy. McGraw-hill London.

Rangkuti, F. (2013). Customer Service Satisfaction \& Call Center Berdasarkan ISO 9001. In 
Jakarta: Gramedia Pustaka Utama.

Sarwoko, E. (2008). Dampak Modernisasi Keberadaan Pasar Modern terhadap Pedagang Pasar Tradisional di Wilayah Kabupaten Malang. Jurnal Ekonomi Modernisasi. https://doi.org/10.21067/jem.v4i2.880

Scriven, J., Clemente, M., Dawes, J., Trinh, G., \& Sharp, B. (2017). Buying brands at both regular price and on promotion over time. Australasian Marketing Journal (AMJ), 25(4), 252-260. https://doi.org/https://doi.org/10.1016/j.ausmj.2017.10.006

Soliha, E. (2008). Analisis Industri Ritel di Indonesia. Jurnal Bisnis Dan Ekonomi (JBE).

Tjiptono, F. (2004). Prinsip-prinsip Total Quality Service. In book.

Utomo, T. J. (2010). Lingkungan Bisnis dan Persaingan Bisnis Ritel ( The Business Environment and the Competition of Retail Business ). Fokus Ekonomi.

Utomo, T. J. (2011). Persaingan Bisnis Ritel: Tradisional vs Modern (The Competition of Retail Business : Traditional vs Modern). Fokus Ekonomi.

van Ooijen, I., Fransen, M. L., Verlegh, P. W. J., \& Smit, E. G. (2017). Packaging design as an implicit communicator: Effects on product quality inferences in the presence of explicit quality cues. Food Quality and Preference, 62, 71-79. https://doi.org/https://doi.org/10.1016/j.foodqual.2017.06.007

Yang, B., \& Mattila, A. S. (2020). How rational thinking style affects sales promotion effectiveness. International Journal of Hospitality Management, 84, 102335. https://doi.org/https://doi.org/10.1016/j.ijhm.2019.102335 
90 Jurnal Ilmiah Ilmu Administrasi Publik: Jurnal Pemikiran dan Penelitian Administrasi Publik Volume io Number 1, January- june 2020. Page 85-90 